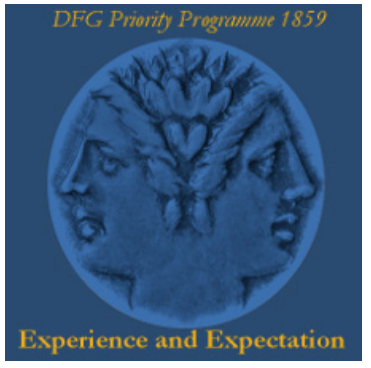

Working Papers of the Priority Programme 1859

Experience and Expectation.

Historical Foundations of Economic Behaviour

Edited by Alexander Nützenadel und Jochen Streb

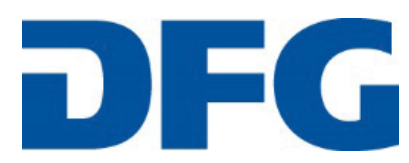

No 1 (2016, September)

Lehmann-Hasemeyer, Sibylle/Streb, Jochen

Does Social Security Crowd Out Private Savings?

The Case of Bismarck's System of Social Insurance 
Arbeitspapiere des Schwerpunktprogramms 1859 der Deutschen Forschungsgemeinschaft „Erfahrung und Erwartung. Historische Grundlagen ökonomischen Handelns“ /

Working Papers of the German Research Foundation's Priority Programme 1859

"Experience and Expectation. Historical Foundations of Economic Behaviour"

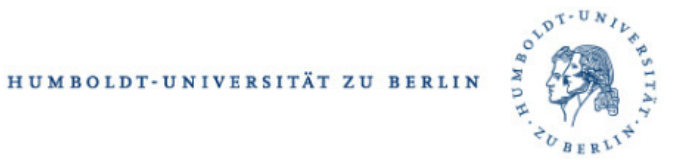

Published in co-operation with the documentation and publication service of the Humboldt University, Berlin (https://edoc.hu-berlin.de).

ISSN: 2510-053X

Redaktion: Alexander Nützenadel, Jochen Streb, Mark Jakob

V.i.S.d.P.: Alexander Nützenadel, Jochen Streb

SPP 1859 "Erfahrung und Erwartung. Historische Grundlagen ökonomischen Handelns"

Sitz der Geschäftsführung:

Humboldt-Universität

Friedrichstr. 191-193, 10117 Berlin

Tel: 0049-30-2093-70615, Fax: 0049-30-2093-70644

Web: https://hu.berlin/spp1859

Koordinatoren: Alexander Nützenadel, Jochen Streb

Assistent der Koordinatoren: Mark Jakob

Recommended citation:

Lehmann-Hasemeyer, Sibylle/Streb, Jochen (2016): Does Social Security Crowd Out Private Savings? The Case of Bismarck's System of Social Insurance. Working Papers of the Priority Programme 1859 "Experience and Expectation. Historical Foundations of Economic Behaviour" No 1 (September), Berlin

The opinions and conclusions set forth in the Working Papers of the Priority Programme 1859 Experience and Expectation. Historical Foundations of Economic Behaviour are those of the authors. Reprints and any other use for publication that goes beyond the usual quotations and references in academic research and teaching require the explicit approval of the editors and must state the authors and original source 


\title{
Does Social Security Crowd Out Private Savings? \\ The Case of Bismarck's System of Social Insurance
}

\author{
Sibylle Lehmann-Hasemeyer, University of Hohenheim \\ Jochen Streb, University of Mannheim
}

September 8, 2016

\begin{abstract}
Imperial chancellor Bismarck's system of social insurance (with its three pillars health, accident and pension insurance) was an important role model for social security systems across Europe and in the US. How the introduction of the German system changed economic expectations and decisions of the German workforce has not been researched, though. This article tries to close this gap by analyzing the development of Prussian savings banks' deposits in the late $19^{\text {th }}$ century. The introduction of social security can affect private savings in at least two different ways: on the one hand, it might induce households to reduce their precautionary savings; one the other hand, it might give people a reason to reflect on their financial needs at old age or when sick, thereby increasing their motivation to accumulate private savings. To identify the causal effect of social insurance on private savings in Prussia, we employ a difference-in-difference-like approach. We show that, in our example, social security crowded out private savings considerably.
\end{abstract}

\section{JEL Codes}

D14, E 21, H55, N33

\section{Corresponding author:}

Prof. Dr. Jochen Streb, Universität Mannheim, L 7, 3-5, D-68131 Mannheim, Germany, streb@uni-mannheim.de

We wish to thank our student assistants who helped to collect the data. Furthermore, we are very grateful for the comments of Alexander Donges, Timothy W. Guinnane, Tobias Jopp, Katerina Piro, and the participants at the workshop "Health and Welfare" in Groningen. The usual disclaimer applies. 


\section{Introduction}

Germany's system of social insurance with its three pillars health, accident and pension insurance that were established by Imperial chancellor Otto von Bismarck in the 1880s was an important role model for social security systems across Europe and in the US. In 1957, however, the German minister for economic affairs Ludwig Erhard predicted the imminent end of the traditional German system because he was strongly convinced that steadily rising per-capita income would soon enable prudent households to increase their precautionary savings solely on the basis of their own responsibility (Erhard, 1957, p. 254). This prediction turned out to be a blatant miscalculation. In that same year chancellor Konrad Adenauer enforced a new German pensions act that automatically linked pension levels to economic growth thereby raising the West German welfare state to a whole new level. ${ }^{1}$ In the following national election, for the first and only time, Adenauer's conservative party CDU won with the absolute majority of votes.

Erhard's arguments in favor of a termination of the traditional social insurance system still provide important insights into the reasons why this system had been introduced in the first place. In the early 1880s, Bismarck and his political advisers assumed that German (blue-collar) workers lacked both the economic capacity and the rational foresight to provide independently for life risks such as old age, illness or invalidity. That is why they decided to force workers to do what was good for them by establishing compulsory social insurance. ${ }^{2}$ Interestingly enough, similar paternalistic arguments had motivated the introduction of savings banks in the early nineteenth century. In particular, savings banks were thought to teach poor people the value of saving (Ashauer, 1998, p. 57).

If the German savings banks fulfilled their educational mission, the question arises whether (and to what extent) the establishment of Bismarck's system of compulsory social insurance actually changed workers' voluntary savings. In theory, social security can affect private savings in at least two different ways (Feldstein, 1974). On the one hand, if households aim for a certain amount of total savings, the introduction of compulsory social insurance might induce them to reduce their voluntary precautionary savings. On the other hand, the introduction of compulsory social insurance might give people a reason to reflect on their financial needs at

\footnotetext{
${ }^{1}$ See Gesetz zur Neuregelung des Rechts der Rentenversicherung der Arbeiter vom 23. Februar 1957, Bundesgesetzblatt I (1957), pp. 45-87; Gesetz zur Neuregelung des Rechts der Rentenversicherung der Angestellten vom 23. Februar 1957, Bundesgesetzblatt I (1957), pp. 88-131.

2 See Kaiserliche Botschaft vom 17. November 1881, Abhandlungen des Reichstags, V. Legislaturperiode, Erste Session, 1881, pp. 1-3.
} 
old age or when sick, thereby also increasing their motivation to build up larger private savings accounts.

Based on information about savings banks' deposits in more than 400 Prussian districts in the decades before the First World War we will analyze which of these effects dominated in the later nineteenth century. To establish causality, we make use of the fact that many occupations were not affected by the introduction of Bismarck's social security system and could therefore be used as a control group, such as miners and public servants who already had a functioning social security system since the middle of the nineteenth century, and selfemployed persons who were not covered by any compulsory social insurance in the period under observation. We employ a difference-in-difference-like approach and show that, in Prussia, social security crowded out workers' private savings considerably.

The paper is organized as follows. Section 2 discusses the relationship between social security and private savings on the basis of the theoretical and empirical literature. Section 3 provides information about the historical development of both savings banks and social insurance in Prussia. In this section, we also elaborate the basic idea of our identification strategy. Section 4 introduces the data. Section 5 presents the empirical analysis. Section 6 concludes.

\section{Related literature}

In the early 1950s, Franco Modigliani and his student Richard Brumberg ${ }^{3}$ developed the life cycle hypothesis of saving which assumes that individuals save during their working years to secure a certain consumption level after their retirement. In his seminal paper, Martin Feldstein (1974) raises the question whether the introduction of compulsory social insurance affects an individual's decision-making about her private savings under the life cycle hypothesis. He assumes a strong substitution effect between these two types of old-age provision. Given that an individual's preferred consumption level at old age does not change with the introduction of social insurance, she will reduce her private savings in the amount of her expected pension claims. In contrast to this view, Philipp Cagan (1965) and George Katona (1965) suggest that pensions and private savings are complements rather than substitutes.

Cagan (1965) stresses the role of the so-called recognition effect. In his opinion, the introduction of social insurance might give people for the first time a reason to consider their financial needs at old age (or when sick or disabled after a work-related accident), thereby

\footnotetext{
${ }^{3}$ Because of the untimely death of Brumberg in August 1954, their joint paper was never published. See Ando and Modigliani (1963).
} 
increasing their motivation to build up private savings. It is the assumed life cycle myopia of workers which is generally used to justify the introduction of paternalistic social security systems of the Bismarckian type (Feldstein/Liebman, 2002, p. 2269). ${ }^{4}$ Katona (1965) assumes that people with low income usually do not save because getting to a level of savings that would allow for an adequate consumption at old age seems out of reach. After the introduction of compulsory social insurance which is partly financed by employers and public subsidies, however, poor people expect to receive pension payments that finance a great deal of their consumption at old age (or when being incapacitated for work). That is why they now have incentives to build up additional private savings in order to bridge the remaining (and comparably small) shortfall in future consumption. Agreeing with Katona's hypothesis, Johnson (1984) claims that British working class people started saving for old age only after the liberal government had introduced (in 1908) a tax-financed and means-tested pension for people older than 70 .

Similar to Johnson's approach scholars usually focus on major political reforms when trying to identify the impact of social insurance on private savings. Kantor and Fishback (1996), for example, focus on the introduction of workers' compensation in American states in the 1910s. They estimate that this institutional change caused private savings to fall by about one quarter. Cutler and Gruber (1996) address the substitution between social and private insurance. They show that the expansion of Medicaid to pregnant women and children in the late 1980s crowded out private health insurance in the US by about 50 percent of the increase in coverage. Andersson and Eriksson (2015) claim that the introduction of a compulsory public pension system in Sweden in 1914 reduced the demand for life insurance significantly but had no measurable effect on private savings at banks.

Surprisingly enough, researchers have long neglected the German experience. This only changed with Beatrice Scheubel (2013) who explores the substitution between social security and a very particular type of old age provision, that is getting many children. Like other industrialized countries Germany experienced a pronounced period of fertility decline at the turn of the previous century when the total fertility rate fell from about 5.5 children per woman in 1885 to less than 2.5 in the 1920 s. Scheubel (2013) argues that the introduction of the social security system in the 1880 s played a larger role in this development than is usually assumed. Her main argument is that pension insurance fully decoupled the motive to provide for old age from the decision to have children. In economic terms, compulsory public insurance crowded

\footnotetext{
${ }^{4}$ In a poor relief system, workers are discouraged to save because they are forced to spend all their savings before they will be entitled to state support. That is another reason why private savings might increase after the introduction of social security.
} 
out any type of investment in private insurance: Employees that became subject to social insurance contributions reduced both private savings for old age and the number of children who were traditionally supposed to support their old and disabled parents. In Scheubel's opinion, the latter substitution effect was intensified by the externalities of the pay-as-you-go system in which the children of other people have to pay for the pensions of childless people.

To test her hypotheses empirically Scheubel relies on cross-sectional observations of the demographic development in the 41 regions (Regierungsbezirke) of the German Empire between 1878 and 1914. Her identification strategy makes use of the fact that the extent to which the population was covered by the newly-introduced social pension insurance differed across German provinces and over time. She employs a difference-in-difference approach in which the treatment group consists of all provinces where the share of insured people was higher than the sample mean plus one standard deviation. Her conclusion is that up to a third of the observable decline in crude birth rates was determined by the introduction and extension of the pension system. Measuring industrialization by the share of population working in mining Scheubel (2013, p. 158) claims that this factor had an independent negative effect on fertility too. We think that this deduction is misleading. Tobias Jopp (2013) shows that German miners had been covered by a sector-specific pension system (very similar to the Bismarckian one) already since the middle of the nineteenth century and therefore faced incentives to reduce their number of children long before the other industrial workers. That is why the share of miners and other compulsory insured people can help to identify German regions with a very early treatment. In the next section, we will use this insight to develop a more refined difference-indifference-like approach to analyze the impact of social security on private savings in Prussian districts.

\section{Institutional change}

Inspired by experiences with earlier financial institutions like pawnshops and orphans' funds, the first German savings banks were founded in the northern parts of the country, namely in Hamburg (1778), Oldenburg (1786), Kiel (1796), and Altona (1801) (Wysocki, 1980, p. 24). In Prussia, where municipal savings banks dominated from the beginning, the first savings bank was established in Berlin in 1818 (Ashauer, 1998). By 1913, the number of savings banks had risen to 1765 in Prussia and 3133 in the whole German Empire (Deutsche Bundesbank, 1976, pp. $63 \mathrm{f}$ ). Measured by their share in the total assets of all German financial institutions in the year 1913, savings banks represented with 24.8 percent the largest group of banks, closely 
followed by incorporated credit banks with 24.2 percent and mortgage banks with 22.8 percent (Guinnane, 2002, p. 81). ${ }^{5}$

The original purpose of savings banks was to provide poor people with the opportunity to build up funds that could be used in times of need. For that reason, some savings banks defined their target group very precisely. The savings bank of Trier, for example, which was located in the Prussian Province Rhineland, planned to accept as depositors only day laborers, domestic servants, soldiers up to the rank of non-commissioned officers, and public servants who earned less than 12 thalers per month (Ashauer, 1998, p. 55). ${ }^{6}$ However, many savings banks did not adhere to their founding principles and also accepted wealthier customers. Other savings banks explicitly opened up to all locals regardless of their income level. It is therefore not surprising that, in the nineteenth century, the lowest social strata accounted for only about 40 to 50 percent of all savings bank books, with an even lower share in savings banks' total deposits (Wysocki, 1980, pp. 76-83).

Yet, executives of the savings banks feared that the introduction of Bismarck's social security system with its three pillars health insurance $(1883)^{7}$, accident insurance $(1884)^{8}$ and pension insurance $(1889)^{9}$ would crowd out private savings (Ashauer (1998, p. 72). The three pillars of the new social security system had in common that they insured all industrial bluecollar workers and those white-collar workers whose annual earnings did not exceed 2000 marks. With respect to insurance benefits, the health insurance provided sick pay and medical treatment for up to thirteen weeks. The accident insurance law required that an injured worker received all medical care free of charge. ${ }^{10}$ The law also included further mandatory benefits based on the worker's income at the time of the accident. A permanently disabled worker, for instance, received two thirds of his last earnings as a pension. Widows and orphans were entitled to a survivor's pension. According to the legal rules of the pension insurance, workers obtained an old-age pension after reaching the age of 70 . This pension payment was not meant

\footnotetext{
${ }^{5}$ Burhop (2002) finds a significant positive relationship between the German savings banks' financial depth and Germany's real capital stock for the period 1883 to 1913 . This result implies that the savings banks' role in financing Germany's small and medium-sized industry was more important than hitherto assumed. See also Proettel (2013).

${ }^{6}$ See also the statues of the early savings banks in Hamburg or Oldenburg published in Wysocki (1980, pp. 198200). The savings banks' lending business is described in Proettel (2013).

${ }^{7}$ The health insurance came effective in December 1884. See Gesetz betreffend der Krankenversicherung der Arbeiter vom 15. Juni 1883 (Reichsgesetzblatt (1883), pp. 73-104).

${ }^{8}$ The accidence insurance came in force in October 1885. See Unfallversicherungsgesetz vom 6. Juli 1884 (Reichsgesetzblatt (1884), pp. 125-133).

${ }^{9}$ The pension insurance became effective in January 1891. See Gesetz betreffend die Invaliditäts- und Altersversicherung vom 22. Juni 1889 (Reichsgesetzblatt (1889), pp. 97-144).

${ }^{10}$ Guinnane and Streb (2015) show that a more consistent use of the rules and the limited incentives available under the accident insurance law would have reduced industrial accidents earlier and more extensively.
} 
to cover the full cost of living but should only compensate for the drop in income that elderly workers had to accept due to their decreasing labor productivity.

The three pillars of social insurance differed considerably with regard to their funding. Employers had to finance all of the expenses of the accident insurance, two thirds of the costs of the health insurance, and half of the financial obligations of the pension insurance. Workers' pay checks were reduced to cover the remainder in each case. In addition, the central government subsidized the pension insurance by providing a grant of 50 marks per insured.

Ashauer (1998, p. 72) claims that German savings banks' worries proved wrong. In his view, the introduction of social insurance in the 1880 s could simply not crowd out private savings because most workers did not save for old age or invalidity but rather for specific consumption needs. Even though Wysocki (1980, p. 88) observes that workers' individual savings deposits were often high enough to cover the living expenses for a whole year, he also does not believe that workers voluntarily saved for retirement or long periods of sickness. Given the impressive increase of savings banks' total deposits that grew in Germany from 2.6 billion in 1880 to 19.7 billion marks in 1913, and in Prussia from 1.6 billion to 13.1 billion marks (Deutsche Bundesbank, 1976, pp. 63 f), both historians felt the need to deny any substitution effect between private savings and social security.

The eightfold increase in savings banks' total deposits in the three decades before the First World War has a lot to do with the fact that both the number of potential savers and the individual saving capacity grew considerably in this period. In the German Empire, population rose between 1880 and 1913 by about 50 percent, real wages by about 60 percent (Rothenbacher/Fertig, 2015, Pierenkemper, 2015). However, this growth-driven increase in savings activities might obscure that, at the same time, social security crowded out private savings.

Our identification strategy follows a similar logic as a standard difference-in-difference approach. Ideally, we would like to compare the individual savings activities of the newlyinsured industrial workers with the savings activities of other people who were potential savers but not affected by Bismarck's social security system policy, either because they already had compulsory insurance or because they were not covered by the new laws. Note, however, that we do not have detailed data about individual Prussian households. That is why we cannot contrast the savings activities of households that were (voluntarily or compulsorily) insured against major life risks with those that were not insured. Based on statistical information about the geographic distribution of different occupational groups we instead focus on comparing savings activities of Prussian districts that differ with respect to their share of persons that were 
most likely affected by Bismarck's social policy. To do this as exactly as possible we have to consider which other occupational groups were already compulsorily insured in our period of observation and which groups were not covered by Bismarck's new social security system. To begin with, miners had already been subject to compulsory social insurance since the middle of the nineteenth century. In 1854 the Prussian government established industry-specific social insurance carriers (so-called Knappschaften) that insured miners against income losses due to temporary sickness, permanent invalidity, and survivorship of a miner's spouse and children. ${ }^{11}$ Since every miner became unfit for mining sooner or later and therefore entitled to a life-long invalidity pension, Jopp (2013, p. 58) argues that Knappschaften implicitly provided old-age pensions. The replacement rates of the miners' social insurance system were relatively generous. The invalidity pension came to about 10 to 30 percent of miners' average income, the daily sick pay amounted to about 30 to 50 percent of miners' daily wages (Jopp, 2013, p. 141).

If miners considered social security and private savings as close substitutes, we would assume that they saved significantly less than other workers who could not hope for sick pay or invalidity pension until the introduction of Bismarck's compulsory social security system. Beginning in the $1880 \mathrm{~s}$, however, when all workers were treated equally with respect to social security, we would expect private savings of miners and other industrial workers to converge.

Farm workers were soon defined as compulsory members both of the accident insurance and the pension insurance. ${ }^{12}$ However, this occupational group remained excluded from Bismarck's health insurance until 1911. Sector-specific social insurance for self-employed farmers was introduced later in the twentieth century, namely accident insurance ${ }^{13}$ in 1939 , pension insurance ${ }^{14}$ in 1957 , and health insurance ${ }^{15}$ in $1973 .{ }^{16}$ Domestic servants who had been one of the major target groups of the early savings banks were for a long time only included in the pension insurance. Since 1911, they were also accepted by the health insurance. As already mentioned above, white-collar workers with an annual income below 2000 marks were treated

\footnotetext{
${ }^{11}$ For the history of Prussian miners' social security system, see Guinnane and Streb (2011) and Jopp (2011, 2012, 2013).

${ }^{12}$ See Gesetz betreffend die Unfall- und Krankenversicherung der in land- und forstwirtschaftlichen Betrieben beschäftigten Personen vom 5. Mai 1886 (Reichsgesetzblatt (1886) pp. 132-178).

${ }^{13}$ See Fünftes Gesetz über Änderungen in der Unfallversicherung vom 17. Februar 1939 (Reichsgesetzblatt (1939) pp. 267-275).

${ }^{14}$ See Gesetz über die Altershilfe für Landwirte vom 27. Juli 1957 (Bundesgesetzblatt I (1957) pp. 1063-1068).

${ }^{15}$ See Gesetz über die Krankenversicherung der Landwirte vom 10. August 1972 (Bundesgesetzblatt I (1972) pp. 1433-1458).

${ }^{16}$ Self-employed persons outside the agricultural sector can voluntarily apply for compulsory membership in the German social insurance system since 1972. See Rentenreformgesetz vom 16. Oktober 1972

(Bundesgesetzblatt I (1972) pp. 1965-1997).
} 
like blue-collar workers. Only in 1912, did white-collar workers with an annual income above 2000 marks also become compulsory members of the social insurance system. ${ }^{17}$ Public servants, however, had benefited from preferential treatment already since 1825 when the Prussian government had entitled them to old age pensions and sick pay. ${ }^{18}$ Even though, Prussian public servants were not members of a compulsory social insurance system in a legal sense, they were in an economic sense because, like the Prussian miners, they were not forced to build up private savings in order to provide for life risks.

To sum up, this short review of social security legislation suggests that we should distinguish three different groups in the following quantitative analysis of savings activities in Prussian districts:

1) employees with the highest likelihood not to change their saving behavior after the introduction of Bismarck's social security system either because they were already compulsorily insured (miners and public servants) or because they were not covered by the new law (self-employed persons) (group 1); ${ }^{19}$

2. all other employees who became compulsory members of one or more pillars of Bismarck's social security system sometime between the 1880s and the First World War (group 2); ${ }^{20}$

3. persons who had no personal income and were therefore reliant on the economic support of the household's breadwinner such as housewives, children and elderly persons (group 3).

We define the second group as our treatment group that is the group of savers that was most likely affected by the introduction of Bismarck's social security system. Note the following caveats.

Some of the employees who were part of the second group could have been voluntarily insured before the 1880s. They could have joined local social security funds that were founded (and financed) by some employers, municipalities, or charities. They could also have bought life insurance that was already offered by private insurance companies (Borscheid, 1988). We consider none of these possibilities because of missing data.

\footnotetext{
${ }^{17}$ See Versicherungsgesetz für Angestellte vom 20. Dezember 1911.

${ }^{18}$ See Preußisches Pensionsreglement für die Civil-Staatsdiener vom 30. April 1825.

${ }^{19}$ Group 1 includes persons without profession (category 24 of the Prussian occupation census of 1882), that is persons whose income was generated by capital assets as well as persons who lived in governmental facilities such as mental institutions or prisons.

${ }^{20}$ Group 2 also comprises the comparatively small group of persons whose occupation was not known (category 23 of the Prussian occupation census of 1882).
} 
As long as they belonged to a working class household the dependents in group 3 were also affected by Bismarck's social security system. Since the newly-established social insurance promised economic support when the breadwinner became sick, disabled or died, dependents now faced less incentive to build up their own savings deposits in order to provide for major life risks. The statistics do not reveal, however, which share of the absolute number of dependent people were part of the newly-treated households of industrial workers. If at all, children or housewives of more wealthy families held their own savings accounts (Wysocki, 1980, p. 77 f). That is why, we abstain from adding the third group to the actual treatment group of employed workers. Instead, we will distinguish below between cases where dependents belonged to the reference population of potential savers and where they did not.

Finally, we do not know the exact date of the beginning of the treatment of the second group. The earliest possible treatment year is 1881 when Bismarck explained his plan to establish a social security system in the Reichstag (German parliament). This public announcement might have already affected workers' long-term expectations and therefore their savings activities. The latest possible treatment year is 1891 when the pension insurance law became effective. Workers might have changed their savings behavior only after they had actually started to contribute to the pension insurance. To deal with this methodological imprecision we experiment with different treatment years in our quantitative analysis.

\section{Data}

The Prussian statistical yearbook (Zeitschrift des Königlich Preußischen Statistischen Landesamt) regularly provided a detailed statistical description of the business activities of the Prussian savings banks. For most of the years in our observation period, however, this information has been aggregated on the level of the 13 Prussian provinces or the 35 Regierungsbezirke, the middle administrative level of the Prussian state. Only for some years, the statistics offer data about every single Prussian savings bank including its number of savings accounts and total deposits. In our observation period, these data are available for the eight calendar years 1874, 1875, 1882, 1888, 1897, 1898, 1903, and 1904. ${ }^{21}$ To get a more disaggregated picture of the geographical distribution of savings activities across Prussia we assigned each individual savings bank to its appropriate district (in the borders of 1871) which is the lower administrative level of the Prussian state.

\footnotetext{
${ }^{21}$ The data are published in the volumes 1876, 1884, 1890, 1900 and 1906 of the Zeitschrift des Königlich Preußischen Statistischen Landesamt.
} 
As a result, we observe savings activities in up to 436 Prussian districts for eight benchmark years in the period from 1874 to 1904 . Three years $(1874,1875,1882)$ lie before the introduction of the first pillar of Bismarck's social security system (health insurance in 1883), five years $(1888,1897,1898,1903,1904)$ cover the period afterwards. Wysocki $(1980$, p. 84) notes that the average German saver made only one or two deposits at her savings bank per year. In the interim, private savings were accumulated at home. Given the low frequency of individual bank payments our annual data seem to be sufficient to identify the impact of social security on private savings in the late nineteenth century. Although not codified in each and every statute, savings banks usually only accepted savers that lived in the boundaries of the district where the respective savings bank was located. That is why local savings deposits are a good indicator for the local propensity to save.

Figure $1 \quad$ Savings banks' deposits per capita in Prussian districts, 1882

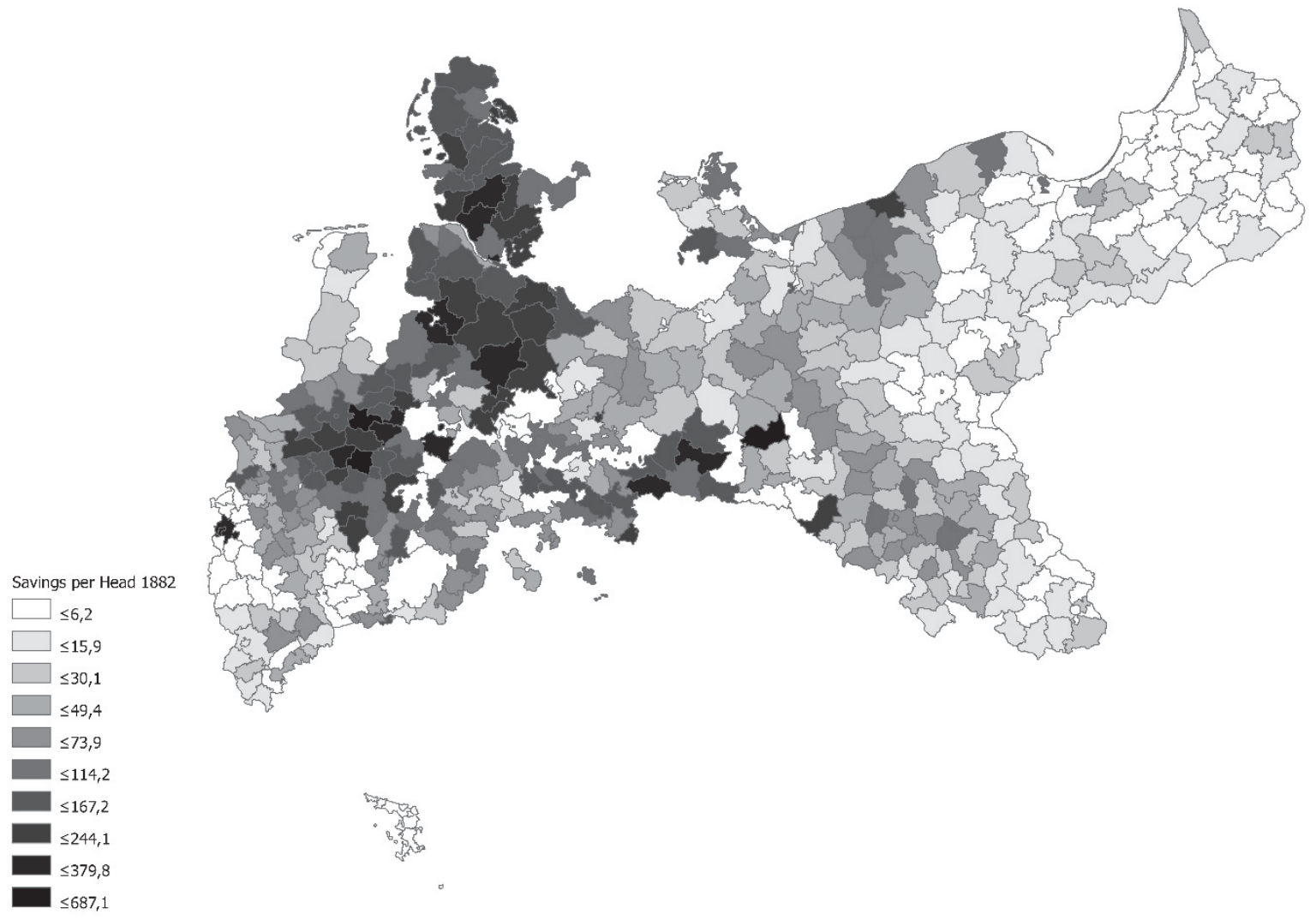

Figures 1 and 2 show that both the amount of savings banks' deposits per capita and the number of savings banks per capita were by no means equally distributed across Prussian districts. The highest savings activities can be found in the Regierungsbezirke Schleswig, Hannover, Westphalia and Rhineland. In the Eastern provinces of Prussia, savings activities were comparatively low. Ashauer (1998, p. 56) suggests that these differences can be explained 
by cultural peculiarities. People from northern Schleswig were known as particularly "thrifty" (or even stingy); people from the Rhineland were "venturous", and the inhabitants of the province Posen in the east had a low "sense of security" and therefore shied away from entrusting a bank with their money. Notwithstanding Ashauer's cultural explanation, it is clear that we do not observe the geographical distribution of Prussian districts' total savings as we do not have information about, for example, households' cash hoarding or savings at other financial institutions such as credit cooperatives or insurance companies. Regional differences in savings banks' deposits per capita might (partly) result from the use of different forms of saving and not from different culture-driven propensities to save. However, this problem should not affect our results as we focus on changes and not on the absolute level of savings banks' deposits at the district level.

Figure 2 Savings banks per capita in Prussian districts, 1882

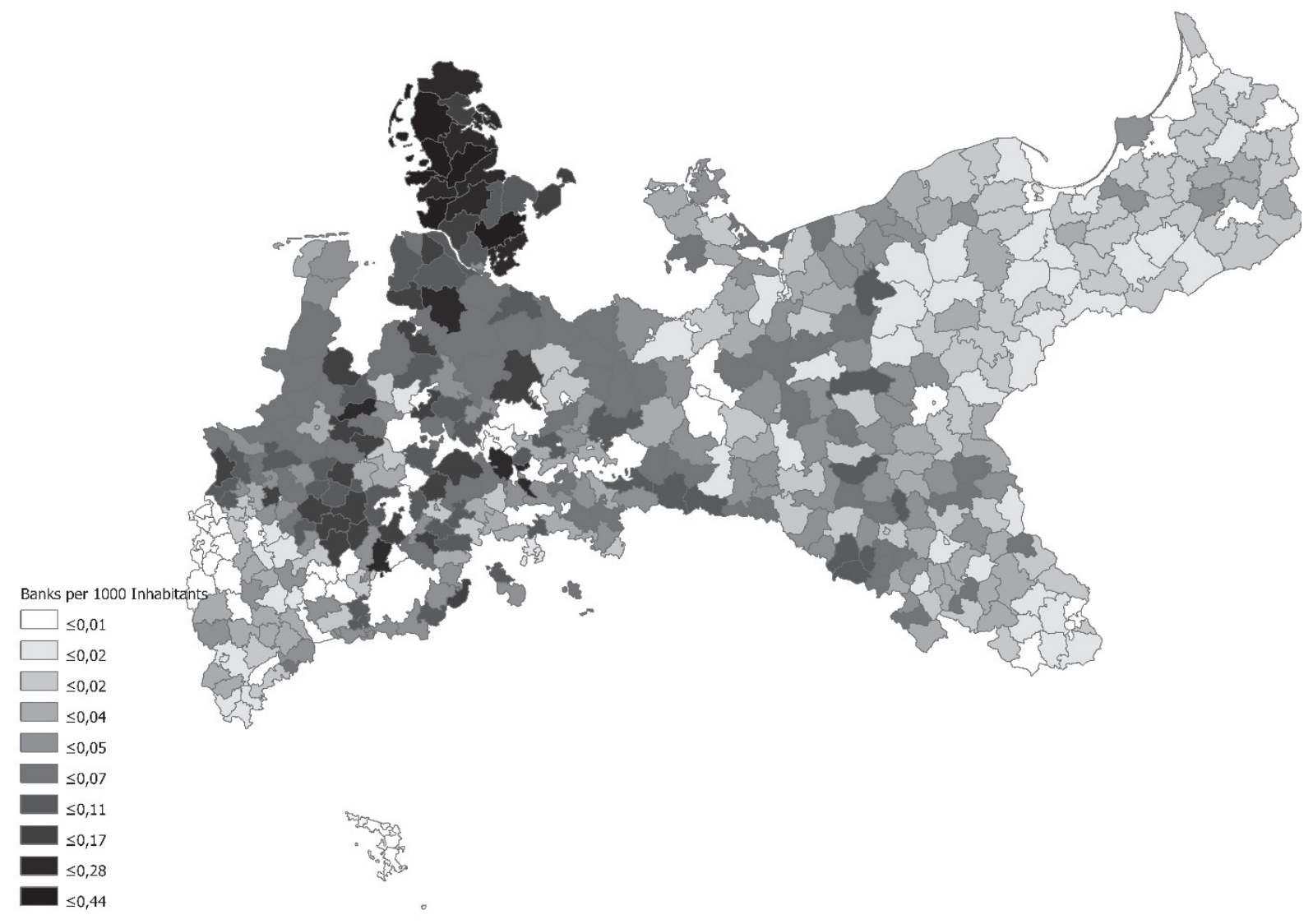


Information about the distribution of employees across occupational groups are taken from the ifo Prussian Economic History Database (Becker et al, 2014). The original source for these data is the Prussian occupation census of $1882 .{ }^{22}$ Figure 3 shows how our treatment group (employees that were neither miners nor public servants) was distributed across Prussia.

Figure 3 The "newly treated": Group 2 in percentage of total population in Prussian districts, 1882

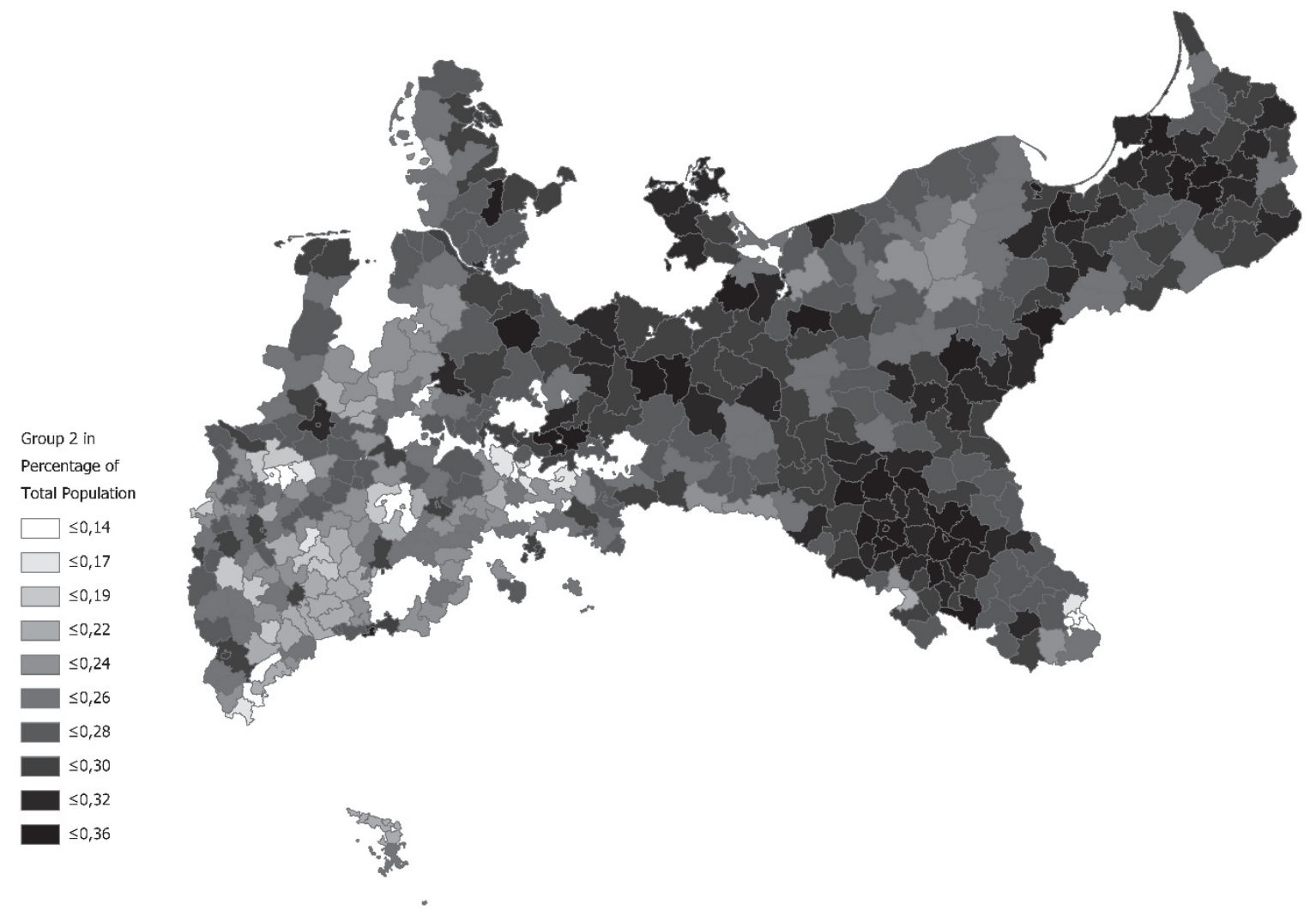

Naturally, the share of newly-treated savers (group 2) was comparatively small in the Prussian regions with rich deposits of coal and nonferrous metals where miners were concentrated, namely in the provinces Rhineland, Westphalia, Saxony, and Silesia. Measured by income tax revenues per capita, these Prussian provinces were also among the most advanced in economic terms (Cinnirella/Streb, 2016). Before the introduction of Bismarck's social security system, relative savings activities in miners' districts were therefore subject to two countervailing influences. On the one hand, given a constant marginal propensity to save, miners (and other workers in these districts) might have saved more because they had a higher average income at their disposal than the people in the less developed non-mining districts. On

\footnotetext{
${ }^{22}$ We assume that, within districts, the distribution of these occupational groups did not significantly change in the following two decades.
} 
the other hand, miners might have had a comparatively low marginal propensity to save (and saved less than non-miners) because they were already entitled to invalidity pensions and sick pay. We will disentangle these two effects in the next section.

Table 1 presents the mean value and standard variation for our main dependent and explanatory variables. The additional control variables were taken from the "Galloway Prussia Database 1861 to $1914 " .{ }^{23}$ We control for the share of old (above 70 years) and the share of young people in a district's population. We assume that workers' savings were lower the more dependent people they had to provide for. ${ }^{24} \mathrm{We}$ further control for the share of women in a district's population thereby accounting for potential gender specific differences in risk aversion and preference for saving. Because urban populations often had higher incomes, we also include the share of population that lived in cities. Since we cover a relatively short period of 29 years, we suppose that other factors which might affect savings activities such as religion or culture remain constant and are therefore captured in the fixed effects. ${ }^{25}$

In the late nineteenth century, Prussia's industrialization came along with a steady growth in real income. All other things equal, we would expect individual savings to increase parallel to real disposable income. To control for this general income effect, we employ year dummies. In addition, we make use of a time series of German real income provided by Rainer Gömmel (1974 [2004]).

\footnotetext{
${ }^{23}$ See Galloway (2007). His data are not available for all years. That is why we matched Galloway's data for the year 1875 with our data on saving banks for the years 1874 and 1875. Saving banks' data from 1882 were associated with Galloway's data from the same year and the year 1880; saving banks' data for 1888 with Galloway's data from 1890. Saving banks' data for the years 1897 and 1898 are matched with Galloway's data from the year 1900; saving banks' data for the years 1903 and 1904 with Galloway's data for 1905.

${ }^{24}$ This assumption is in line with the life cycle hypothesis that assumes that old people dis-save.

${ }^{25}$ Savings banks' interest rates hardly changed over time and ranged between 2.5 and 4.5 percent (Ashauer, 1998, p. 58). The fact that interest rates were generally higher in the Western provinces of Prussia is covered by the district fixed effects.
} 


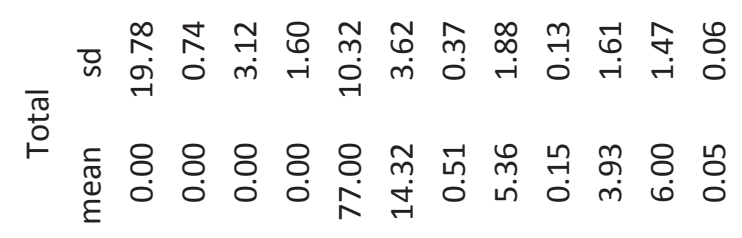

염

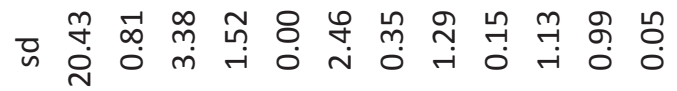

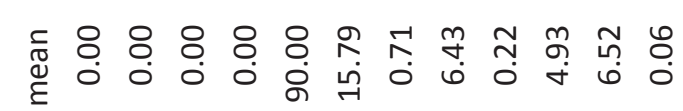

亩

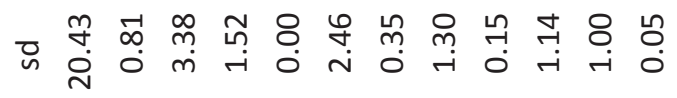

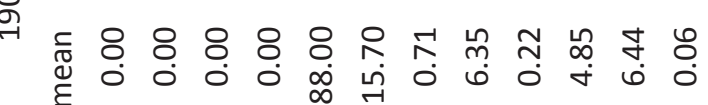

फ

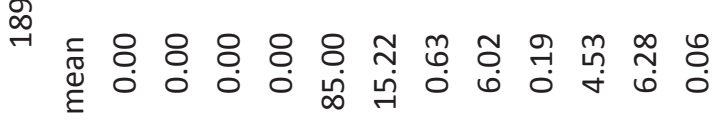

๙ิ

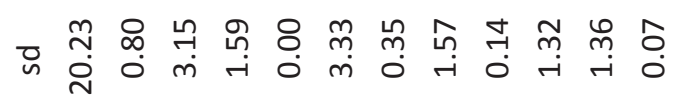

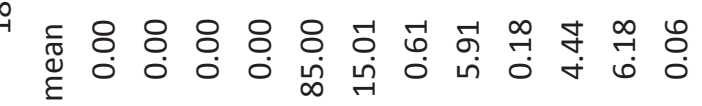

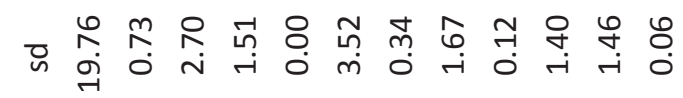

$\stackrel{\infty}{\infty}$

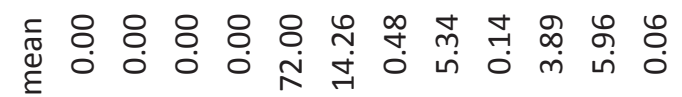

$\underset{\infty}{\infty}$ ஸ $\begin{aligned} & 0 \\ & \infty\end{aligned}$

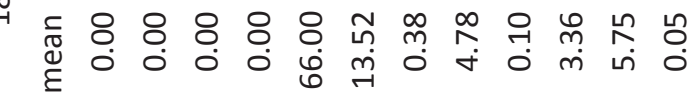

$\underset{\substack{n \\ \rightarrow}}{\substack{\infty \\-1}}$

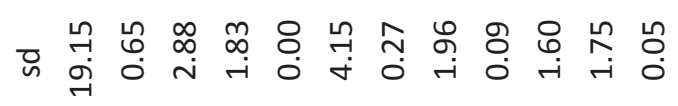

资

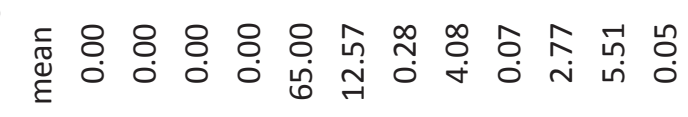

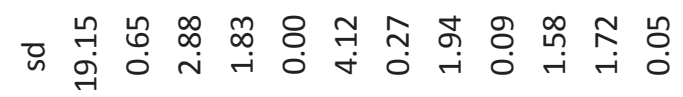

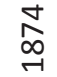

Æ

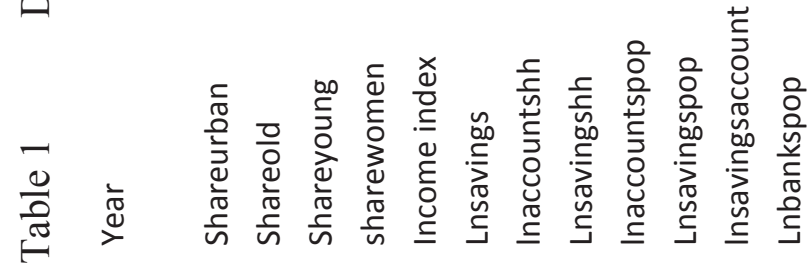




\section{Empirical analysis}

We analyze the impact of social security on private savings at the level of Prussian districts with the help of seven alternative measures for the dependent variable, all in natural logarithm. ${ }^{26}$ Most importantly, we consider as dependent variables the amount of savings banks' deposits (lnsavings), savings banks' deposits per capita (lnsavingspop), and savings banks' deposits per household (Insavingshh). In addition, we use information about the number of savings accounts, again in absolute numbers (lnaccounts), per capita (lnaccountspop) and per household (lnaccountshh). Finally, we look at a district's number of savings banks per capita (lnbankspop). By comparing savings activities of Prussian districts that differ with respect to their share of persons with a high likelihood to be affected by Bismarck's social security system, our estimation strategy follows the same logic as a standard differences-indifferences approach. The special feature of our method is the use of a continuous measure for the intensity of the treatment, thereby making better use of the variation in the data. Our main hypothesis is that, after the introduction of Bismarck's social security system, savings grew more slowly in districts with a large share of newly-treated employees (group 2) than in districts with a comparatively small share of this group because in the former districts relatively many people started to replace private savings with social insurance.

In our regression analysis we distinguish two potential treatment variables. The first treatment variable ( $\mathrm{T}$ 1) relates the treatment group (group 2: employees that were neither miners nor public servants) to a district's total population. We therefore assume that every person whether self-employed, employed, or economically dependent is a potential saver.

$\mathrm{T} 1=($ group $2 /$ district's population $) * 100$

In contrast, the second treatment variable ( $\mathrm{T} 2$ ) is based on the assumption that only persons with their own income can actively make savings decisions. That is why housewives, children and other dependent persons (group 3) are not considered as potential savers and therefore excluded from the reference population in the denominator: ${ }^{27}$

$\mathrm{T} 2=($ group $2 /($ district's population - group 3$)) * 100$.

\footnotetext{
${ }^{26}$ In some Prussian districts, there existed no savings banks at the beginning of our observation period. We therefore observe zero savings for some district-years. In order to keep these observations in the regression analysis, we increase every observation by one before taking the natural logarithm.

${ }^{27}$ The Pearson correlation coefficient of the treatment variables T 1 and T 2 is 0.8570 .
} 
To mark the beginning of the treatment period, we introduce the dummy variable Bismarck which equals one for all observation years after the year 1883, in which the first pillar of Bismarck's social insurance, that is health insurance, was introduced. ${ }^{28}$ Our identification strategy focuses on the interaction between Bismarck and the treatment variables 1 or 2 respectively. If social security indeed crowded out private savings, the coefficient of the interaction terms inter 1 and inter 2 should be negative. With respect to treatment variable 1 , the results are shown in Tables 2 and 3. Tables 4 and 5 present the regressions for treatment variable 2.

To consider the fact that the introduction of Bismarck's social security system played only a minor role in districts that were still dominated by agriculture we also run regressions that only included the 374 Prussian districts where the share of agricultural workers was below 20 percent (see Tables 3 and 5). All our models are estimated with district fixed effects and clustered standard errors at the level of districts.

\footnotetext{
${ }^{28}$ We also experimented with alternative beginning-of-the-treatment years. The year 1883 , however, led to the comparatively best fit of our regression models.
} 


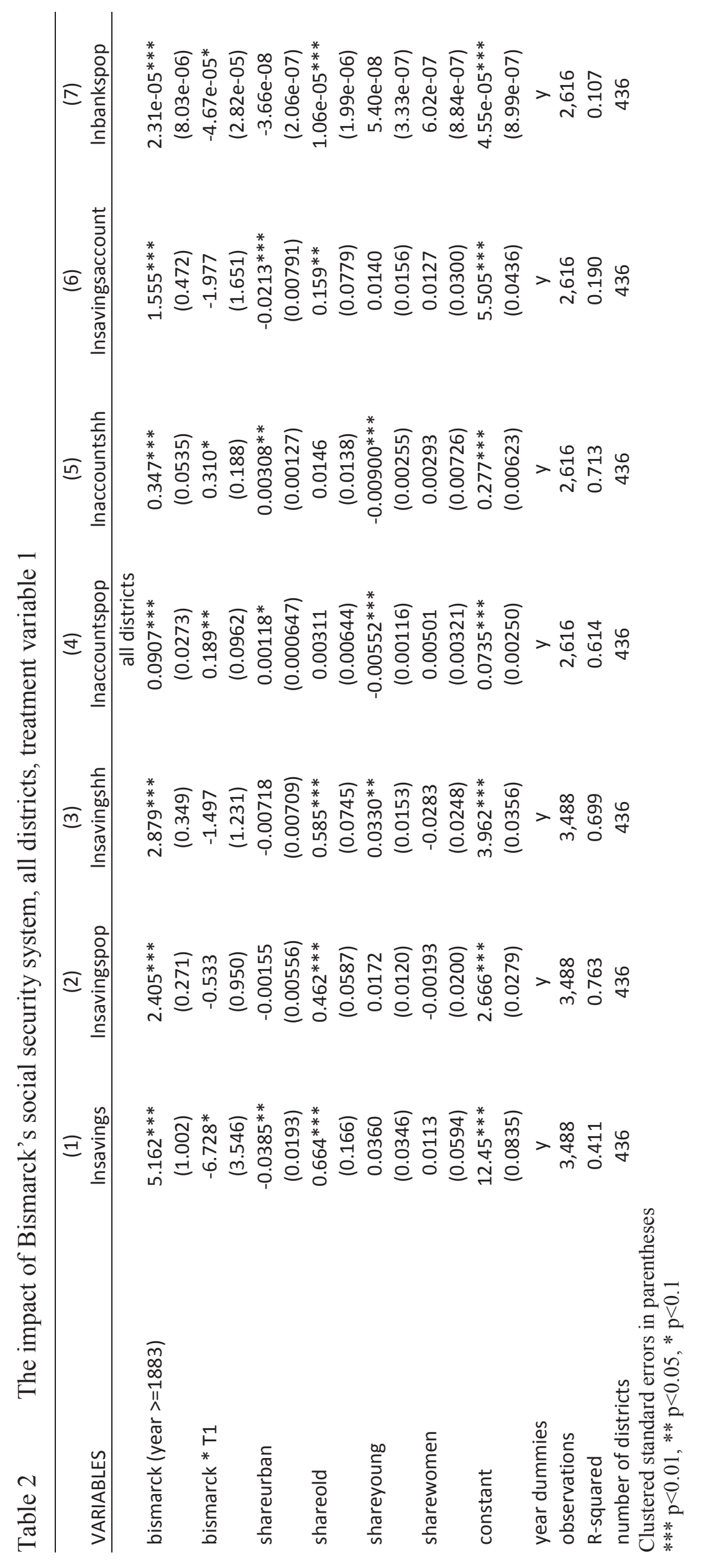




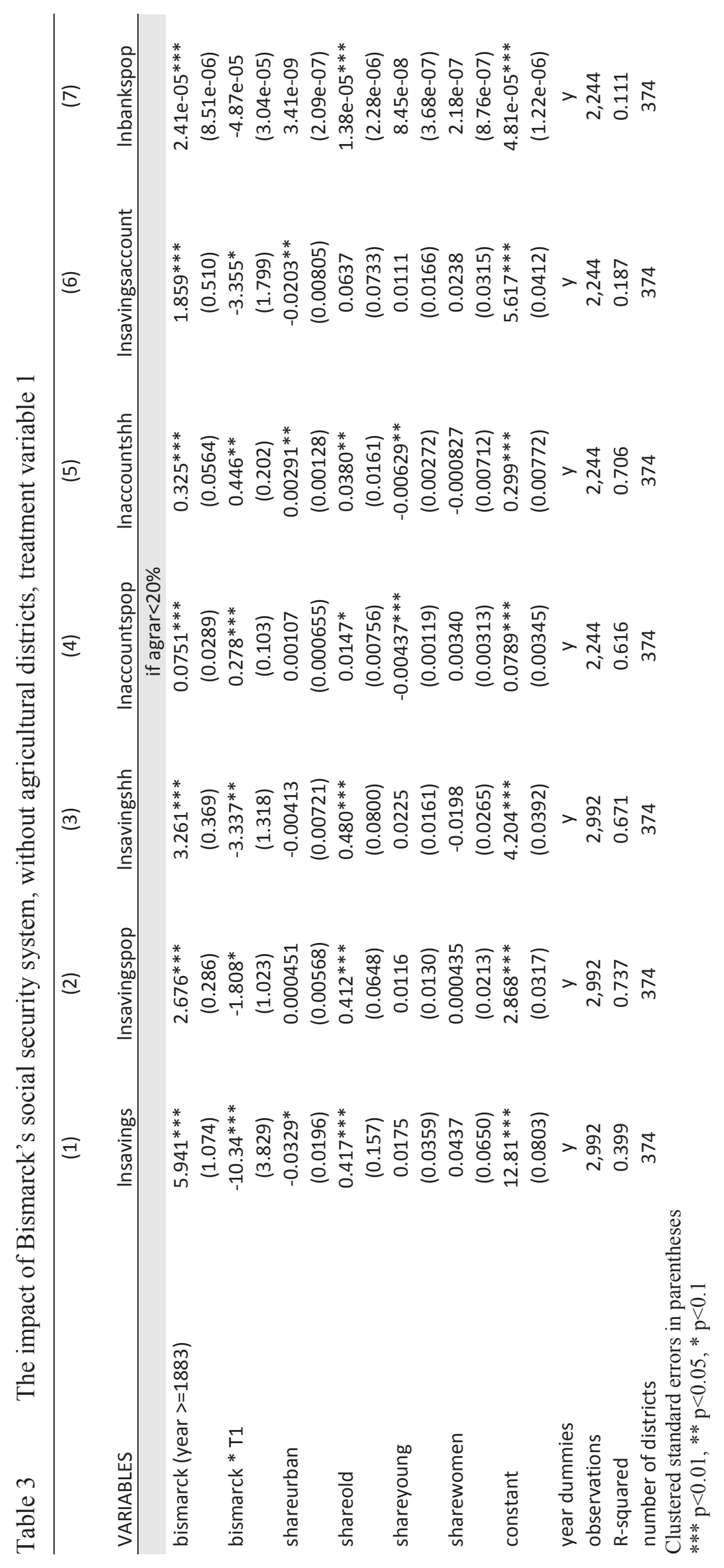




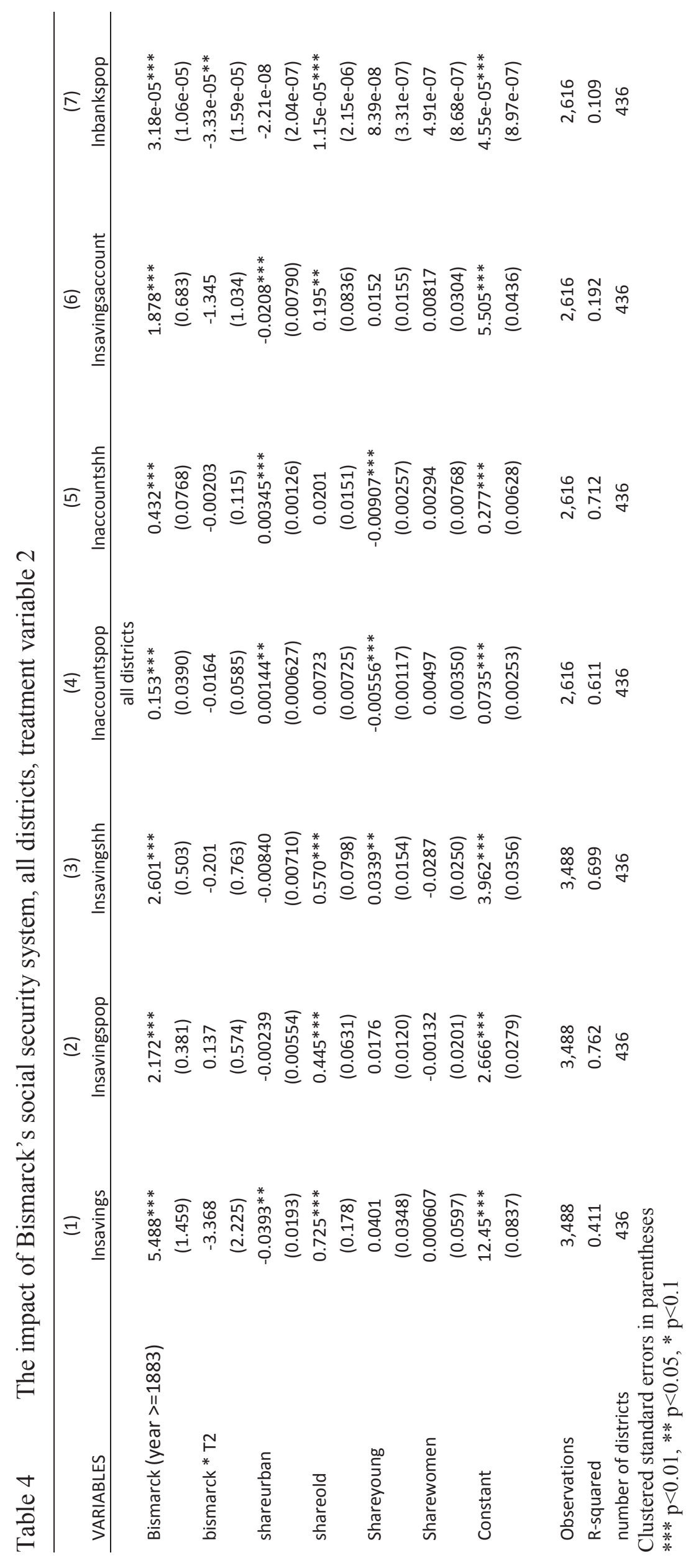




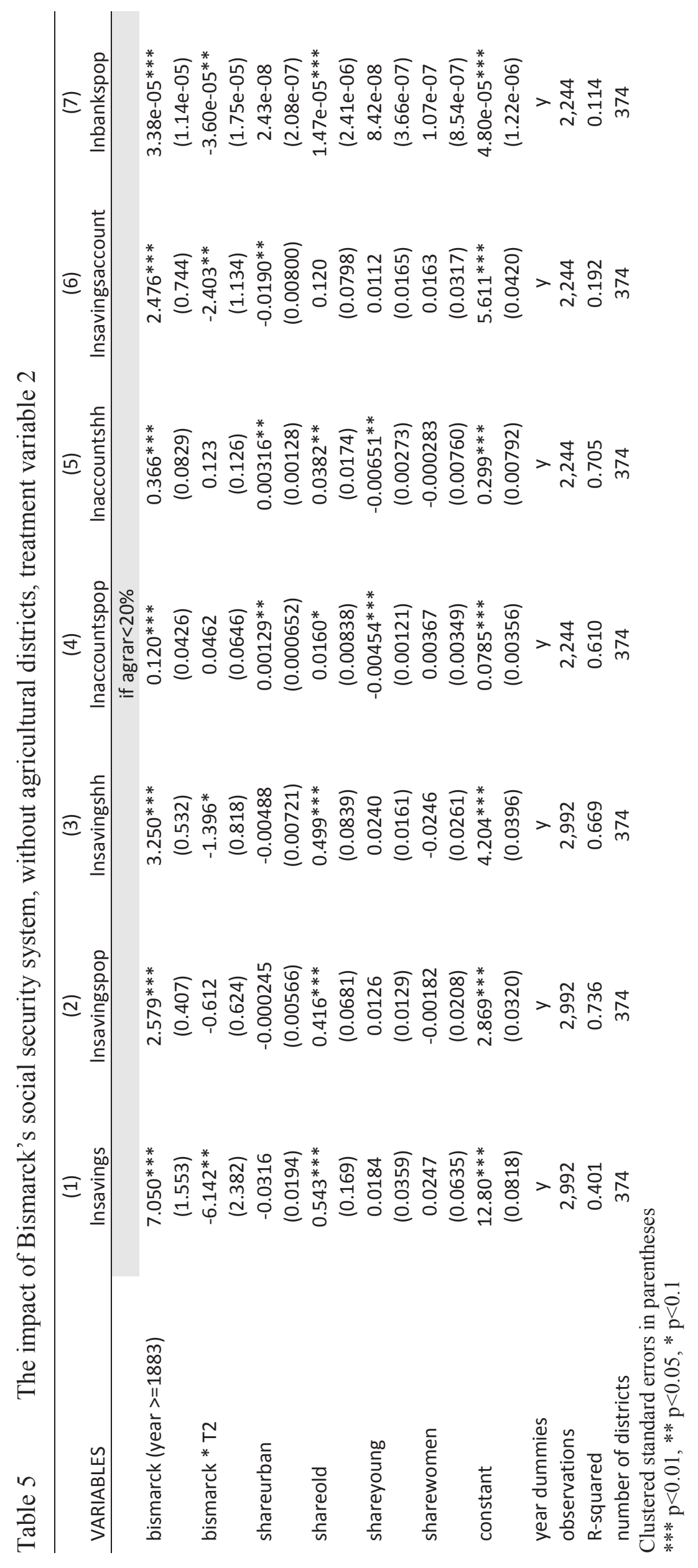


Surprisingly enough, in all specifications, the dummy variable Bismarck is significantly and positively related to savings banks' deposits, the number of savings accounts, and the number of savings banks. After the introduction of Bismarck's social security system, in Prussia, more savings banks were founded, more people opened up a savings account, and households saved more than in the decade before. The positive relationship between Bismarck and the various dependent variables suggests the existence of an education effect in line with Cagan's (1965) argument. Being forced to contribute to the social security funds might have taught Prussian workers to recognize the value of voluntary private savings. Alternatively, Katona (1965) would argue that it was the new prospect of getting an old age or invalidity pension that encouraged workers to save more in order to close the remaining gap in the envisaged future retirement income. A reason against the conclusion that social security and private savings were complements is that the year dummies which are otherwise positive and significant become insignificant with the introduction of the Bismarck dummy. This result implies that the Bismarck dummy also picks up the strongly increasing real wages since the 1880 s.

With respect to the role of the interaction term our findings are less robust. However, we want to point out that the first three estimates in Table 3 clearly imply that the introduction of Bismarck's social security system crowded out private savings in non-agricultural districts. In the specification that assumes that the only persons that could make saving decisions were people with their own income (Tables 4 and 5) the impact of the interaction term on savings activities is in general smaller but also more significant. Interestingly enough, the interaction term is positively related with the number of savings accounts per capita and per household. After the introduction of Bismarck's social security system, Prussian workers might have opened up additional savings accounts because of an increased willingness to save but in total they saved less than they would have done without social security.

One might argue that the negative interaction term with respect to savings deposits does not indicate crowding out but simply reflects the fact that, after 1882, the income of group 1 rose faster than that of group 2. This was not the case. Gumbach and König (1957 [2005]) provide information on the development of wages in Imperial Germany. They show that the income of miners (in group 1) did not increase faster than that of industrial worker (in group 2). Hoffmann's (1961, pp. 492 f) estimates confirm this finding. Selgert (2013) studied living standards of public servants in the region Baden in the period 1780 to 1913 . He finds that the relative position of public servants in the income distribution seemed to deteriorate from the second half of the 19th century onwards when blue collar workers' real wages started to 
increase while district magistrates' remuneration stagnated or even decreased. On balance, these studies suggest that the income of group 2 grew at least as fast as the income of group 1.

Contrary to our expectations, a high share of old people in a district's total population is positively associated with savings banks' total deposits. Obviously, old people had built up a considerable amount of private savings during their working life but they did not use most of it for actual consumption at old age, as Modigliani's life cycle theory suggests. Our finding implies that a bequest motive was already operative.

To get a better understanding about the timing of the treatment effect, in Table 6 , we interact treatment variables 1 and 2 with every observed year. With regard to the dependent variable, we now focus on savings deposits per household (lnsavingshh). The sign of the yearspecific interaction terms' coefficients is still positive albeit not significant in the year 1875 which suggests that group 2 did not save comparatively less than group 1 before the introduction of Bismarck's social security system. The year-specific interaction terms' coefficients become robustly negative in 1888 and increase both in size and significance during the 1890s and early 1900. ${ }^{29}$ Our finding that the crowding-out effect increased over time implies that Prussian workers needed time to understand the economic implications of compulsory social security. Only after experiencing that social insurance benefits were provided by the government as originally promised they did change their long-term expectations and saved less.

In Table 6, we also include the German real income index provided by Gömmel (1974 [2004]). The results show that private savings at savings banks indeed increased with rising prosperity. This "income effect" explains why both contemporaries and historians so far failed to recognize the crowding out effect that took place despite increasing savings in absolute terms.

\footnotetext{
${ }^{29}$ As a robustness check, we ran a similar regression for the 35 Prussian Regierungsbezirke (regions) for which we have data for each year between 1878 and 1903. The results are similar but less significant. The regression table will be provided in the online appendix.
} 
Table 6 The timing of the treatment

\begin{tabular}{|c|c|c|c|c|c|c|c|c|}
\hline \multirow[t]{3}{*}{ VARIABLES } & $\begin{array}{c}\text { (1) } \\
\text { Lnsavings } \\
\text { hh }\end{array}$ & $\begin{array}{c}\text { (2) } \\
\text { Lnsavings } \\
\text { hh }\end{array}$ & $\begin{array}{c}\text { (3) } \\
\text { Lnsavings } \\
\text { hh }\end{array}$ & $\begin{array}{c}\text { (4) } \\
\text { Lnsavings } \\
\text { hh }\end{array}$ & $\begin{array}{c}\text { (5) } \\
\text { Lnsavings } \\
\text { hh }\end{array}$ & $\begin{array}{c}\text { (6) } \\
\text { Lnsavings } \\
\text { hh }\end{array}$ & $\begin{array}{c}\text { (7) } \\
\text { Lnsavings } \\
\text { hh }\end{array}$ & $\begin{array}{c}\text { (8) } \\
\text { Lnsavings } \\
\text { hh }\end{array}$ \\
\hline & \multicolumn{4}{|c|}{ all districts } & \multicolumn{4}{|c|}{ if agrar $<20$} \\
\hline & \multicolumn{2}{|c|}{ Treatment1 } & \multicolumn{2}{|c|}{ Treatment2 } & \multicolumn{2}{|c|}{ Treatment1 } & \multicolumn{2}{|c|}{ Treatment2 } \\
\hline \multirow[t]{2}{*}{$1875 * T$} & 0.126 & 0.126 & 0.0791 & 0.0791 & 0.118 & 0.118 & 0.0755 & 0.0755 \\
\hline & $(0.228)$ & $(0.228)$ & (0.0939) & (0.0939) & $(0.265)$ & $(0.265)$ & $(0.113)$ & $(0.113)$ \\
\hline \multirow[t]{2}{*}{$1882 * T$} & 0.842 & 0.842 & $1.473 * * *$ & $1.473^{* * *}$ & -0.516 & -0.516 & 0.674 & 0.674 \\
\hline & $(1.020)$ & $(1.020)$ & $(0.518)$ & $(0.518)$ & $(1.100)$ & $(1.100)$ & $(0.542)$ & $(0.542)$ \\
\hline \multirow[t]{2}{*}{$1888 * T$} & -0.265 & -0.265 & 0.840 & 0.840 & -2.014 & -2.014 & -0.137 & -0.137 \\
\hline & (1.255) & (1.255) & $(0.733)$ & $(0.733)$ & $(1.338)$ & $(1.338)$ & $(0.774)$ & $(0.774)$ \\
\hline \multirow[t]{2}{*}{$1897 * T$} & -0.532 & -0.532 & 0.923 & 0.923 & $-2.869 *$ & $-2.869 *$ & -0.492 & -0.492 \\
\hline & $(1.472)$ & $(1.472)$ & $(0.889)$ & $(0.889)$ & $(1.580)$ & $(1.580)$ & (0.959) & (0.959) \\
\hline \multirow[t]{2}{*}{$1898 * T$} & -1.282 & -1.282 & 0.227 & 0.227 & $-3.601 * *$ & $-3.601 * *$ & -1.299 & -1.299 \\
\hline & (1.468) & (1.468) & $(0.884)$ & $(0.884)$ & (1.587) & $(1.587)$ & $(0.952)$ & $(0.952)$ \\
\hline \multirow[t]{2}{*}{$1903 * T$} & -1.793 & -1.793 & -0.125 & -0.125 & $-4.362 * *$ & $-4.362 * *$ & $-1.881^{*}$ & $-1.881^{*}$ \\
\hline & (1.577) & (1.577) & $(0.972)$ & $(0.972)$ & $(1.726)$ & $(1.726)$ & (1.051) & (1.051) \\
\hline \multirow[t]{2}{*}{$1904 * T$} & -1.988 & -1.988 & -0.187 & -0.187 & $-4.616^{* * *}$ & $-4.616^{* * *}$ & $-1.986 *$ & $-1.986^{*}$ \\
\hline & (1.577) & (1.577) & $(0.977)$ & $(0.977)$ & (1.722) & (1.722) & (1.052) & (1.052) \\
\hline \multirow[t]{2}{*}{ bismarck } & & 1.352 & & 1.097 & & $1.768^{*}$ & & 1.809 \\
\hline & & $(0.849)$ & & (1.056) & & $(0.923)$ & & $(1.175)$ \\
\hline \multirow[t]{2}{*}{ shareurban } & -0.00714 & -0.00714 & -0.00860 & -0.00860 & -0.00387 & -0.00387 & -0.00483 & -0.00483 \\
\hline & $(0.00719)$ & $(0.00719)$ & $(0.00735)$ & $(0.00735)$ & $(0.00726)$ & $(0.00726)$ & $(0.00739)$ & (0.00739) \\
\hline \multirow[t]{2}{*}{ Shareold } & $0.584^{* * *}$ & $0.584^{* * *}$ & $0.565^{* * *}$ & $0.565^{* * *}$ & $0.481^{* * *}$ & $0.481^{* * *}$ & $0.502^{* * *}$ & $0.502^{* * *}$ \\
\hline & $(0.0750)$ & $(0.0750)$ & $(0.0810)$ & $(0.0810)$ & $(0.0803)$ & $(0.0803)$ & $(0.0844)$ & $(0.0844)$ \\
\hline \multirow[t]{2}{*}{ shareyoung } & $0.0329 * *$ & $0.0329 * *$ & $0.0370 * *$ & $0.0370^{* *}$ & 0.0201 & 0.0201 & 0.0219 & 0.0219 \\
\hline & $(0.0155)$ & $(0.0155)$ & $(0.0158)$ & $(0.0158)$ & $(0.0162)$ & $(0.0162)$ & (0.0165) & $(0.0165)$ \\
\hline \multirow[t]{2}{*}{ Sharewomen } & -0.0279 & -0.0279 & -0.0291 & -0.0291 & -0.0185 & -0.0185 & -0.0232 & -0.0232 \\
\hline & $(0.0248)$ & $(0.0248)$ & $(0.0250)$ & $(0.0250)$ & $(0.0267)$ & $(0.0267)$ & $(0.0261)$ & $(0.0261)$ \\
\hline \multirow[t]{2}{*}{ income_index } & $0.120 * * *$ & $0.0664 * *$ & $0.104 * * *$ & $0.0598^{*}$ & $0.144^{* * *}$ & $0.0733^{* *}$ & $0.145^{* * *}$ & $0.0724^{*}$ \\
\hline & $(0.0177)$ & $(0.0301)$ & $(0.0256)$ & $(0.0361)$ & $(0.0190)$ & $(0.0326)$ & $(0.0271)$ & $(0.0401)$ \\
\hline \multirow[t]{2}{*}{1875} & 0.0810 & 0.0810 & 0.0648 & 0.0648 & 0.0837 & 0.0837 & 0.0678 & 0.0678 \\
\hline & $(0.0642)$ & $(0.0642)$ & $(0.0615)$ & $(0.0615)$ & $(0.0718)$ & $(0.0718)$ & $(0.0707)$ & $(0.0707)$ \\
\hline \multirow[t]{2}{*}{1882} & $0.470^{*}$ & $0.524^{*}$ & -0.226 & -0.182 & $0.742^{* * *}$ & $0.812^{* * *}$ & 0.183 & 0.255 \\
\hline & $(0.270)$ & $(0.279)$ & (0.321) & $(0.332)$ & $(0.286)$ & $(0.296)$ & $(0.331)$ & (0.341) \\
\hline 1888 & $0.605^{* *}$ & -0.369 & 0.113 & -0.677 & $0.831^{* * *}$ & -0.443 & 0.378 & -0.924 \\
\hline & $(0.277)$ & $(0.584)$ & $(0.387)$ & $(0.741)$ & $(0.293)$ & (0.641) & $(0.411)$ & $(0.847)$ \\
\hline 1897 & -0.317 & $-0.587^{*}$ & $-0.715^{*}$ & $-0.935 * *$ & -0.265 & $-0.619 *$ & -0.732 & $-1.094 * *$ \\
\hline & $(0.253)$ & $(0.299)$ & $(0.393)$ & $(0.450)$ & $(0.274)$ & $(0.327)$ & $(0.445)$ & $(0.514)$ \\
\hline 1898 & -0.00144 & -0.272 & -0.158 & -0.378 & 0.0455 & -0.308 & -0.111 & -0.473 \\
\hline & (0.196) & $(0.243)$ & $(0.276)$ & $(0.332)$ & $(0.214)$ & $(0.268)$ & $(0.310)$ & (0.379) \\
\hline 1903 & 0.108 & & 0.0878 & & $0.141^{*}$ & & 0.145 & \\
\hline & $(0.0679)$ & & $(0.0845)$ & & $(0.0738)$ & & $(0.0940)$ & \\
\hline constant & $-3.869 * * *$ & -0.354 & $-2.777^{*}$ & 0.0762 & $-5.156 * * *$ & -0.558 & $-5.205^{* * *}$ & -0.503 \\
\hline & (1.159) & (1.958) & $(1.673)$ & (2.348) & $(1.244)$ & $(2.120)$ & $(1.772)$ & $(2.606)$ \\
\hline observations & 3,488 & 3,488 & 3,488 & 3,488 & 2,992 & 2,992 & 2,992 & 2,992 \\
\hline R-squared & 0.700 & 0.700 & 0.700 & 0.700 & 0.672 & 0.672 & 0.671 & 0.671 \\
\hline number of districts & 436 & 436 & 436 & 436 & 374 & 374 & 374 & 374 \\
\hline
\end{tabular}

Clustered standard errors in parentheses

$* * * \mathrm{p}<0.01, * * \mathrm{p}<0.05, * \mathrm{p}<0.1$ 
The question remains whether this crowding-out effect was also economically significant. To get an idea about its magnitude we used model 5 of Table 6 to calculate the counterfactual savings per household that would have occurred if Bismarck's social security system would not have been introduced - which means that we neglected all year-specific interaction terms. This counterfactual only covers the crowding-out effect but not the offsetting effect suggested by Cagan (1965) or Katona (1965). As explained above, we are not able to identify this latter effect with the help of the Bismarck dummy because this variable also captures some of the general increase in savings that was driven by real wage growth. Figure 4 shows the results of this exercise. At the mean, savings per household in a counterfactual world without social security would have been more than 250 percent higher than savings per household in the actual world of the year 1904. Even if we consider the problem of the unobserved offsetting effect, it is clear that the crowding out effect is also economically significant.

Figure 4 The magnitude of the crowding-out effect

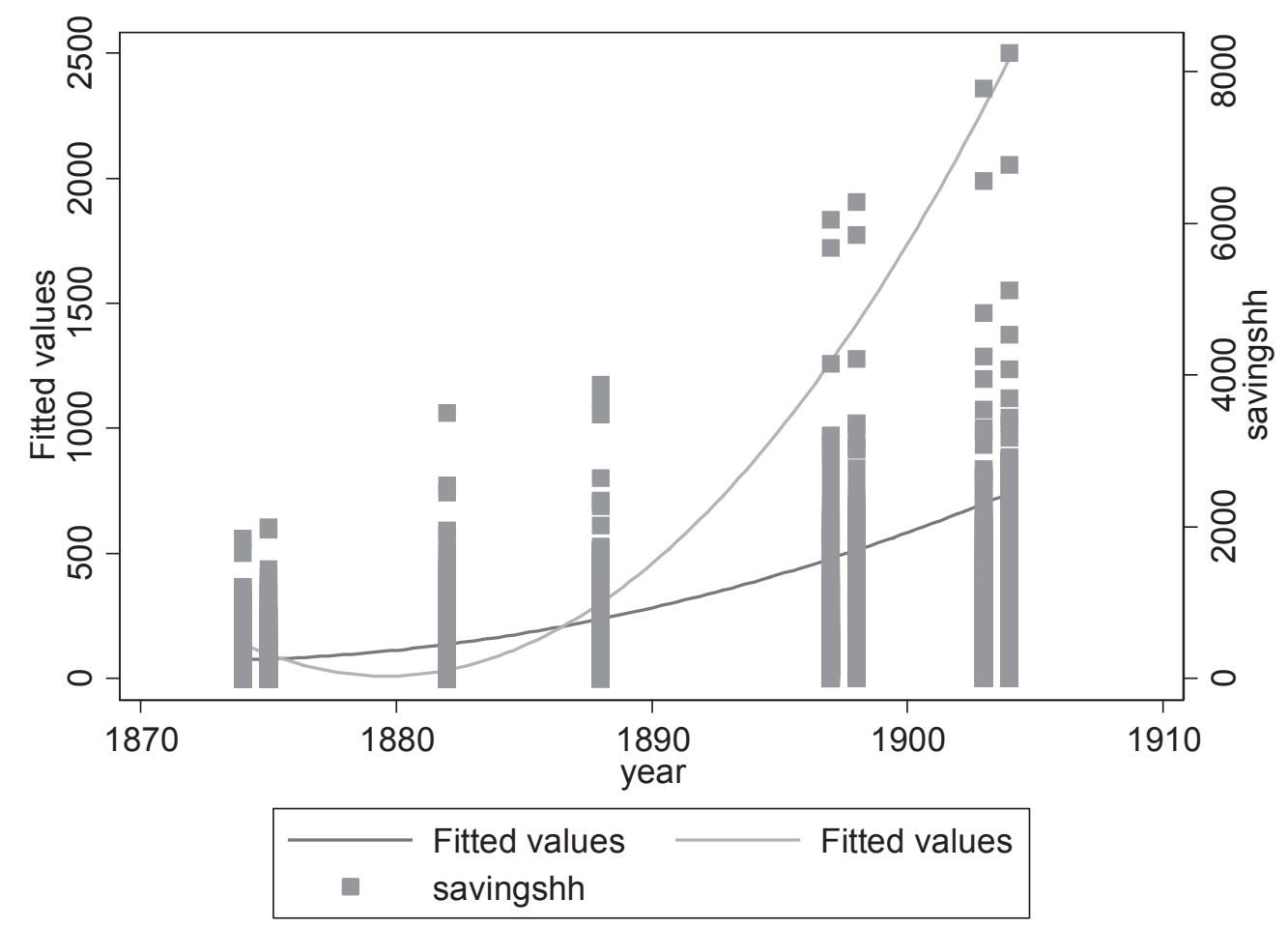




\section{Conclusion}

Politicians - both today and in the past - usually justify the introduction of compulsory social security systems with ordinary people's incapacity to provide self-reliantly for life risks such as old age, invalidity, and sickness. This was also true when chancellor Bismarck introduced the German system of social insurance with its three pillars health, accident, and pension insurance in the 1880 s, considered the birth of the modern welfare state. Opponents of the expansion of the welfare state argue that social security systems are paternalistic and crowd out prudent individuals' precautionary measures and are therefore unnecessary.

Analyzing the impact of social security on private savings in late-nineteenth century Prussia we found evidence for both views. The overall effect, however, seems to be negative. Our regression analysis suggests that the introduction of social security for large parts of the Prussian population crowded out private savings considerably. We can only speculate whether workers would have used their growing real wages to provide self-reliantly for life risks if Bismarck's social security system would not have been established. Based on the data provided by Jopp (2016), we can estimate that, around 1900, the total value of a workers' pension claim ranged between 1.500 and 2.500 marks (which equaled about two annual incomes). Actual savings did not come close. However, our counterfactual suggests that a worker with average wage would have saved about this amount in a world without Bismarck's social security.

This speculation does not consider the distribution of wages across Prussian workers. Even during prime industrialization, many workers might not have yet reached a level of disposable income that would have allowed sufficient individual provision for life risks. Thus Bismarck's social insurance system might indeed have been needed to fight the misery workers and their families potentially faced in old age or sickness. 


\section{References}

Andersson, Lars-Frederik and Liselotte Eriksson (2015), The Compulsory Public Pension and the Demand for Life Insurance. The Case of Sweden, 1884-1914, Economic History Review 68, 244-263.

Ando, Albert and Franco Modigliani (1963), The Life Cycle Hypothesis of Saving: Aggregate Implications and Tests, American Economic Review 53, 55-84.

Ashauer, Günter (1998), Die ökonomische und soziale Bedeutung der preußischen Sparkassen im 19. Jahrhundert, Bankhistorisches Archiv 24, 55-86.

Becker, Sascha, Francesco Cinnirella, Erik Hornung and Ludger Wößmann (2014), Ipehd The ifo Prussian Economic History Database, Historical Methods: A Journal of Quantitative and Interdisciplinary History 47, 57-66.

Borscheid, Peter (1988), Kurze Geschichte der Individual- und Sozialversicherung in Deutschland, in Peter Borscheid and Anette Drees (eds.), Versicherungsstatistik 1750-1985, Scripta Mercaturae Verlag, St. Katharinen, 3-49.

Burhop, Carsten (2002), Did Banks Cause the German Industrialization?, Explorations in Economic History 43, 39-63.

Cagan, Phillip (1965), The Effect of Pension Plans on Aggregate Saving: Evidence from a Sample Survey, National Bureau of Economic Research, New York.

Cinnirella, Francesco and Jochen Streb (2016), the Role of Human Capital and Innovation in Economic Development: Evidence from Post-Malthusian Prussia, Revise \& Resubmit Journal of Economic Growth.

Cutler, David M. and Jonathan Gruber (1996), Does Public Insurance Crowd Out Private Insurance? Quarterly Journal of Economics 111, 391-430.

Deutsche Bundesbank (ed.) (1976), Deutsches Geld- und Bankenwesen in Zahlen 1876-1975, Fritz Knapp Verlag, Frankfurt/Main.

Erhard, Ludwig (1957), Wohlstand für alle, Econ Verlag, Düsseldorf.

Feldstein, Martin (1974), Social Security, Induced Retirement, and Aggregate Capital Accumulation, Journal of Political Economy 82, 905-926.

Feldstein, Martin and Jeffrey B. Liebman (2002), Social Security, in Alan J. Auerbach and Martin Feldstein (eds), Handbook of Public Economics, Vol. 4, Elsevier, Amsterdam, 22452324.

Galloway, Patrick R. (2007), Galloway Prussia Database 1861 to 1914, www.patrickgalloway.com.

Gömmel, Rainer (1979 [2004]), Realeinkommen in Deutschland. Ein internationaler Vergleich (1810-1914), GESIS Köln, Deutschland ZA8167, Datenfile Version 1.0.0.

Guinnane, Timothy W. (2002), Delegated Monitors, Large and Small: Germany's Banking System, 1800-1914, Journal of Economic Literature 40, 73-124.

Guinnane, Timothy W. and Jochen Streb (2011), Moral Hazard in a Mutual Health-Insurance System: German Knappschaften, 1867-1914, Journal of Economic History 71, 70-104.

Guinnane, Timothy W. and Jochen Streb (2015), Incentives that (could have) Saved Lives: Government Regulation of Accident Insurance Associations in Germany, 1884-1914, Journal of Economic History 75, 1196-1227. 
Grumbach, Franz and Heinz König (1957 [2005]), Beschäftigung und Löhne der deutschen Industriewirtschaft 1888-1954, GESIS Köln, Deutschland ZA8213, Datenfile Version 1.0.0.

Hoffmann, Walther G. (1965), Das Wachstum der deutschen Wirtschaft seit der Mitte des 19. Jahrhunderts, Springer, Heidelberg.

Johnson, Paul (1984), Self-Help versus State Help: Old Age Pensions and Personal Savings in Great Britain, 1906-1937, Explorations in Economic History 21, 329-350.

Jopp, Tobias (2011), Old Times, Better Times? German Miners' Knappschaften, Pay-as-yougo Pensions, and Implicit Rates of Return, 1854-1913, Business History 53, 1018-1043.

Jopp, Tobias (2012), Insurance, Size, and Actuarial Risk: Empirical Evidence from Nineteenthand Early Twentieth-Century German Knappschaften, Financial History Review 19, 75-116.

Jopp, Tobias (2013), Insurance, Fund Size, and Concentration: Prussian Miners' Knappschaften in the Nineteenth-and Early Twentieth-Centuries and their Quest for Optimal Scale, Akademie Verlag, Berlin.

Jopp, Tobias (2016), After Us, the Deluge: German Miners' Experience with Pay-as-you-go Pensions and the Intergenerational Contract Before the Great Inflation, Economic History Review, 69, 972-998.

Kantor, Shawn Everett and Price V. Fishback (1996), Precautionary Saving, Insurance, and the Origins of Workers' Compensation, Journal of Political Economy 104, 419-442.

Katona, George (1965), Private Pensions and Individual Saving, University of Michigan Survey Research Center, Ann Arbor.

Pierenkemper, Tony (2015), Arbeit, Einkommen und Lebensstandard, in Thomas Rahlf (ed.), Deutschland in Zahlen: Zeitreihen zur historischen Statistik, Bundeszentrale für politische Bildung, Bonn, 142-153.

Proettel, Thorsten (2013), Die Darlehensvergabe der Oberamtssparkasse Kirchheim unter Teck 1907 bis 1913: Eine Sparkasse als regionale Finanzierungsquelle für Gewerbe und Infrastruktur, Zeitschrift für Unternehmensgeschichte 58, 3-27.

Rothenbacher, Franz and Georg Fertig (2015), Bevölkerung, Haushalte und Familien, in Thomas Rahlf (ed.), Deutschland in Zahlen: Zeitreihen zur historischen Statistik, Bundeszentrale für politische Bildung, Bonn, 30-45.

Scheubel, Beatrice (2013), Bismarck's Institutions: A Historical Perspective on the Social Security Hypothesis, Mohr Siebeck, Tuebingen.

Selgert, Felix (2013), Civil Servants' Living Standards in the Grand-Duchy of Baden, 1780 1913, Jahrbuch für Wirtschaftsgeschichte/Economic History Yearbook 54, 153-179.

Wysocki, Josef (1980), Untersuchungen zur Wirtschafts- und Sozialgeschichte der deutschen Sparkassen im 19. Jahrhundert, Deutscher Sparkassenverlag, Stuttgart.

Zeitschrift des Königlich Preußischen Statistischen Landesamt, various volumes 